\title{
US-China Competition from a Perspective of Global Product Network: Trends and Implications of Industrial Competitiveness between Countries Using Product Space Model
}

Author(s): Jinhee Yoo, Jun Yeop Lee, Hwa-Joong Kim

Source: Journal of International Logistics and Trade 2021; 19(4):197-210

Published by: Jungseok Research Institute of International Logistics and Trade, Inha University

DOI: https://doi.org/10.24006/jilt.2021.19.4.197

Journal of International Logistics and Trade is an official journal published by Jungseok Research Institute of International Logistics and Trade, Inha University, Korea. JILT welcomes manuscripts that advance the practice and science of logistics, trade, and other related fields.

Frequency: Quarterly (March, June, September, December)

Stable URL: https://www.ejilt.org

Jungseok Research Institute of International Logistics and Trade is a specialized academic research institute representing Inha University and Inha Foundation in Korea. The institute aims to become a representative institute in Northeast Asia in the research of logistics and trade.

Stable URL: https://jrieng.inha.ac.kr

(C) Copyright. Jungseok Research Institute of International Logistics and Trade.

This is an Open-Access article distributed under the terms of the Creative Commons Attribution NonCommercial License (http://creativecommons.org/licenses/by-nc/4.0/) which permits unrestricted noncommercial use, distribution, and reproduction in any medium, provided the original work is properly cited 



\title{
US-China Competition from a Perspective of Global Product Network: Trends and Implications of Industrial Competitiveness between Countries Using Product Space Model
}

\author{
Jinhee Yoo ${ }^{1}$, Jun Yeop Lee ${ }^{1,}{ }^{*}$, Hwa-Joong Kim ${ }^{2}$ \\ ${ }^{1}$ Department of International Trade and Regional Studies, Inha University, Incheon 22212, Korea \\ ${ }^{2}$ Asia Pacific School of Logistics, Inha University, Incheon 22212, Korea
}

\section{Received August 24, 2021 \\ Revised November 6, 2021}

Accepted November 25, 2021

*Corresponding author: Jun Yeop Lee
Department of International Trade and
Regional Studies, Inha University, Incheon
22212, Korea
Tel: +82-32-860-7804
Fax: +82-32-863-1337
E-mail: jylee@inha.ac.kr

\begin{abstract}
This study aims to examine the trend of industrial competition between the US and China, which is the most crucial determinant in the future development of the global economy. For decades, the global economy has strengthened the global production network based on the division of labor between countries. Thus, the ripple effect of competition between the two countries should be analyzed in terms of the global production network. Therefore, this study uses the product space model, which explains the development process of industries with comparative advantage by country. We constructed the model based on the products of HS 4-digit code for the 2010-2019 period. The analysis results on the trend of the industrial competitiveness of major countries are as follows. First, the current industrial competitiveness of China is concentrated on low-tech industries. In the case of high-tech items, China shows a tendency of lower export sophistication compared to major manufacturing powerhouses such as Germany, the US, Japan, and Korea. Second, with respect to the possibility of a future industrial structure upgrade evaluated by density, the trend of China overtaking other manufacturing powerhouses is observed. As implied by the product space model, the advancement of the industrial structure through active participation in international trade enhances the industrial competitiveness. Therefore, the outcome of US-China industrial competition depends on who ensures more openness and industrial complexity.
\end{abstract}

Keywords Product space model, Product proximity, PRODY index, EXPY index, USChina competition

\section{Introduction}

Can China continue to climb the ladder of industrial upgrading by overcoming the industrial blockade strategy of the US? US-China competition began with Trump administration's the imposition of tariffs on goods from China and is expanding into industrial and technological competition under the Biden administration. In particular, the Biden administration presented rebuilding a global supply network excluding China as a definite goal ${ }^{1}$. In accord with the policy goal of the US government, the main trend in US industrial policies will be the expansion of the domestic manufacturing base of the critical industries in the US and the construction of supply chains centered in US allies against China.

China is deemed to have successfully climbed the development ladder through technology acquisition in the process of market opening for foreign-invested companies and government-led strong industrial policies since its reform and opening-up

\footnotetext{
${ }^{1}$ The White House released a 100-day review report on the supply chains of the U.S. in sectors such as semiconductors, batteries, core materials, and pharmaceuticals. The main content of the report is that China is an emerging economic powerhouse in these critical sectors, and the production and innovation capabilities of the US have been weakened. (The White House, Building Resilient Supply Chains, Revitalizing American Manufacturing, and Fostering Broad-based Growth, 100-Day Reviews under Executive Order 14017, June 2021).
} 
policy in 1978 (Colotla et al. 2018; Deloitte 2016; Wei et al. 2016). The major factors that have contributed to China's economic success are considered to be manufacturing cost competitiveness based on cheap labor (Colotla et al. 2018), a long-term strategic policy system in which the central government, local governments, national research institutes, and companies participate (Chen and Naughton, 2016), participation in global value chains and technology acquisition by Chinese companies as a result of the increase of international trade (Zhang and Gallagher 2016), and 'innovative manufacturing' unique to Chinese companies (Nahm and Steinfeld 2014). The trend of China's increasing industrial competitiveness has also been confirmed in Deloitte's study (Deloitte 2016) on the global manufacturing competitiveness index ${ }^{2}$ and a UNIDO report (UNIDO 2020) on the global manufacturing competitiveness ${ }^{3}$.

There are opposing views on the effects of US policies toward China. On the one hand, it is claimed that US policies would not control China's growth, would not affect the resolution of the US employment problem or the US trade deficit, but is likely to have a negative impact on both the US economy and the global economy (Hass and Denmark 2020; Huang and Smith 2020). On the other hand, it is argued that China would be relatively severely affected by US policies toward China. Generally, Freund et al. (2018), Itakura (2020), and Walmsley and Minor (2018), which quantitatively evaluated the effect of the tariff increase, which was a policy measure taken toward China by the Trump administration, found that the impact of tariff hikes on the decrease of China's economic growth rate was estimated to be relatively greater.

Regardless of these conflicting views, the US-China trade war is highly likely to lead to changes in the global production network. An empirical analysis of WTO (2020) showed that the increase of policy uncertainty due to the US-China trade war and resulting decreases of exports and investments have more significant negative impacts than the effects of retaliatory tariffs imposed by the two countries. Therefore, it is important to observe the effects of US-China competition in terms of competitiveness in the global production network rather than bilateral trade relations. The trends of changes in the product competitiveness of the US and China are likely to have a fundamental long-term impact on the two countries and the global production network.

This study examines the US-China competition in terms of the difference in industrial competitiveness between the two countries. More specifically, using the product space model proposed by Hidalgo et al. (2007), this study attempts to examine the industrial competitiveness and trend changes of each country in terms of the positions in the entire product network occupied by comparative advantage products of each country. In the current international trade system, all the countries in the world are closely connected to form a global value chain. Therefore, it can be used as an alternative research method to evaluate the industrial competitiveness of a country by the positions of specific product items in the global production network rather than the comparative advantage of the goods.

China achieved its economic growth in a short period of time, maintaining its strong competitiveness in the manufacturing sector. However, to evaluate China's industrial competitiveness and, in particular, its future competitiveness, it is required to analyze its position in the global production network. This is because the network positions of China's current competitive advantage products and that of the future comparative advantage products are crucial in evaluating China's industrial competitiveness.

In this context, this study aims to find answers to the following questions. First, what are critical products from the product space model perspectives? To answer this question, we look at the top 20 PRODY products from 2010 to 2019 and products with high EXPY contribution in the US and China. Second, when the industrial competitiveness of each country is evaluated using the product space model, what are the differences in industrial competitiveness between China, the US, and major countries and the trends of changes in the industrial competitiveness of the countries? To answer this question, we examine the visualization of the world trade product network, the top US-China's revealed comparative advantage (RCA) items using the proximity matrix, and the trend of changes in EXPY contribution by technology level and country. Third, is China likely to carry out its industrial upgrade successfully? In other words, this study seeks to predict the possibility of China's industrial upgrade compared with other major countries. To answer this question, we examine industries' density by country and technology level during the 2010-2019 period.

This study is organized as follows. Section 2 presents a literature review of related studies, and Section 3 offers primary analysis results, including the methodology of the product space model, data, and the proximity network. In Section 4, the

${ }^{2}$ China maintained the top position in 2010, 2013, and 2016 in the manufacturing competitiveness index based on a survey among the CEOs of global companies.

${ }^{3}$ Germany was ranked first, China second, Korea third, and the US fourth showing that China's competitiveness in manufacturing surpassed that of the US. 
trends of changes in the industrial competitiveness of each country are examined by identifying the major products of each country and their positions in the product space model. In Section 5, the path and possibility of China's industrial upgrade are evaluated using the product space model, and the implications for the US-China trade war and major countries are derived in the final section.

\section{Literature review}

The 'Great Convergence', coined by Baldwin (2016), has driven a highly divided global production network. The core of the evolving global production network is China's active participation in world trade and US-China cooperation. In this context, the US-China competition can be analyzed from a global production network perspective. The global production network has been analyzed using the network analysis method in many studies, e.g., De Benedictis and Tajoli (2011), Hidalgo et al. (2007), Kim and Shin (2002), and Pacini et al. (2021). However, there is no network analysis study on the change of the global production network after the US-China trade war to the best of our knowledge. The lack of research updates may be due to the difficulty in constructing updated trade data. However, the product space model used in this study is an alternative methodology that allows for overcoming a lack of trade data.

The product space model is used to identify the relationship between industrial development, international trade, and economic growth in various ways. For example, the product space model is being applied in various fields such as the development potential and economic growth of industries with comparative advantage at the regional economic level rather than the national level (Cicerone et al. 2020; Lee and Park 2017), and comparative analysis of industrial competitiveness between Korea, China, and Japan (Lee and Son 2019), prediction of export industry patterns in a specific country (De La Cruz and Riker 2012), the development potential of specific industries such as green product by country (Hamwey et al. 2013), performance analysis on corporate innovation support policies at the micro-level export subsidies and polices (Desmarchelier et al. 2018). The product space model developed its theoretical system through the proposal of several important concepts. The model asserts that the centrality of a specific product with a comparative advantage in a country is a determinant of the country's economic development based on the network between products at the national level (Hausmann and Kilnger 2007; Hausmann et al. 2007; Hidalgo and Hausmann 2009; Hidalgo et al. 2007). For this analysis, Hidalgo et al. (2007) first established a product space model as a proximity network between products calculated by the conditional probability based on the RCA. The RCA is an index showing a certain country's relative advantage or disadvantage in a certain product. In a proximity network, more sophisticated products are located in densely connected cores.

In addition, Hidalgo et al. (2007) proposed a density conceptualizing the possibility of industrial development as an advanced product through the distance between products in the product network. Hidalgo et al. (2007) identified why developing countries challenge converging their income levels with developed countries by combining the proximity network and the density. The reasons are the initial location of the developing countries and their relatively long distance from the product network, hence proximity between difficult-to-reach products. Expanding this discussion, complexity is correlated with a country's income level, and deviations from this relationship are predictive measures of future growth (Ferrarini and Scaramozzino 2015; Hidalgo and Hausmann 2009).

In the same context, the basic assumption of the product space model is that the product basket with comparative advantage expressed as export products determines a country's economic growth. That is, in the context of "what you export matters", Hausmann et al. (2007) proposed the PRODY and EXPY indices. EXPY is the measure of the productivity level associated with a country's specialization pattern. Hausmann et al. (2007) showed that EXPY exerts an independent force on economic growth. Therefore, by combining the density of Hidalgo et al. (2007) and EXPY of Hausmann et al. (2007), it is possible to quantify both the reachability of a product combination in a country in the future and the sophistication level of these product combinations.

\section{Product space model}

In this study, we constructed a product space model for the 2010-2019 period, based on the HS 4-digit code item classification of the UN Comtrade database. The product space model is a model which attempts to merge international trade theory, economic growth theory, and network theory. In other words, the model is based on the hypothesis that the position in the product network given as the initial condition for a country determines the path of economic growth, based on the notion of traditional economics theory that international trade positively influences economic growth. In addition, the paths of comparative advantage products in the product network varied according to the income level facilitating a dynamic analysis of the process of the industrial 
upgrade of a country.

Traditional trade theory emphasizes comparative advantage and production specialization as crucial factors for economic growth. Accumulated capital and enhanced technology with international trade enable the country to upgrade its industrial structure. In this sense, economic growth can be a continuous upgrade process of comparative advantage products through international trade. However, traditional trade theory does not specify the products with similar levels of capital intensity. Traditional trade theory assumes that different compositions between products with the same capital intensity homogeneous economic growth. Therefore, it does not consider the linkage between the products' combination and the industrial network structure of the country to the industrial upgrade and the economic growth. On the contrary, the product space model attempts to supplement the trade theory of traditional economics using network analysis techniques. First, Hidalgo et al. (2007) suggested the product space map that visualizes the network structure between products. Through this, it is possible to infer a country's future product space map. Second, through the PRODY index proposed by Hausmann et al. (2007), the sophistication level of each product on the product space map is quantified. Through this, it analyzes whether the composition of products in a country is advanced. Third, indicators that measure the complexity of the network in the product space map, such as density, are proposed (Hidalgo et al. 2007). These indicators enable quantifying the potentials of the process in which the product network complexity leads to the next growth stage. In other words, in the product space model, the higher the complexity of the country's products combination, the more potential to upgrade its industry, eventually, the higher potential of the economic growth.

As in the analogy given by Hidalgo et al. (2007), in a product space model, products are described as trees, and the entire industry is viewed as a forest consisting of trees. Monkeys live moving through trees by jumping from tree to tree. The feeding activity of monkeys (individual countries) is closely related to their initial positions. They can easily move between closely located trees but have difficulty moving between trees located at a great distance from each other. The product space model assumes that the industrial upgrade of individual countries is also likely to be affected by initial industries with comparative advantage and the network of nearby products. Individual countries also achieve industrial upgrades by starting from industries with comparative advantage determined by initial endowments and transitioning technological innovations and production activities from industries with comparative advantage to nearby industries.

Therefore, the crucial part of the product space model is the quantification of the degree of linkage between products. The proximity between products is represented as the conditional probability of the RCA based on exports (Hidalgo et al. 2007). A country is deemed to have a comparative advantage in a product once the RCA of the country in the good is greater than 1 . The RCA of country $i$ in product $k, R C A_{i k}$, is calculated as follows.

$$
R C A_{i k}=\frac{X_{i k} / \sum_{j \in C} X_{i j}}{\sum_{j \in C} X_{j k} / \sum_{j \in C} \sum_{l \in P} X_{j l}}
$$

where $X_{i k}$ indicates the exports of product $k$ in country $i, C$ is the set of countries, and $P$ is the set of products. The proximity between a pair of good $k$ and $k^{\prime}, \varphi_{k, k^{\prime}}$, is set as the minimum out of the two conditional probabilities of the RCA, defined as

$$
\varphi_{k, k^{\prime}}=\min \left\{\operatorname{Pr}\left(R C A_{k} \geq 1 \mid R C A_{k^{\prime}} \geq 1\right), \operatorname{Pr}\left(R C A_{k^{\prime}} \geq 1 \mid R C A_{k} \geq 1\right)\right\}
$$

where $\operatorname{Pr}\left(R C A_{k} \geq 1\right)$ is the probability that the RCA of any country for product $k$ is not less than 1 . In addition to the network characteristics of products, the PRODY index proposed by Hausmann et al. (2007) is also used to measure the level of sophistication of an item. The PRODY index of item $k, P R O D Y_{k}$, is a weighted average of the Gross Domestic Product (GDP) per capita of the countries exporting the item, where the weights are the exporting countries' RCA indices for the item.

$$
P R O D Y_{k}=\sum_{i \in C} R C A_{i k} Y_{i}
$$

where $Y_{i}$ represents GDP per capita of country i. Therefore, an item with a high share of exports of high-income countries has a high PRODY index. For example, if semiconductors account for a high proportion of the export of a high-income country, the PRODY index of semiconductors is calculated to be a high value.

After obtaining the PRODY index, we can obtain the level of the sophistication of a country's export basket, which is called 
the EXPY index. The EXPY index of country $i, E X P Y_{i}$, is a weighted average of the PRODY values with weight of a product given to the share of the product in the exports of the country, which is defined as follows.

$$
E X P Y_{i}=\sum_{k \in P} \frac{X_{i k}}{\sum_{j \in P} X_{i j}} P R O D Y_{k}
$$

Countries exporting relatively more goods with a high PRODY index have a higher EXPY index. There is a close positive correlation between GDP per capita and the EXPY index, as can be found in Figure 1. In other words, in terms of international trade, high-income countries can be regarded as those intensively exporting products with a relatively higher PRODY index.

The EXPY contribution level of item $k$ in country $i, E X P Y_{-} C_{i k}$, is defined as follows. The level is an element of EXPY index.

$$
E X P Y_{-} C_{i k}=\frac{X_{i k}}{\sum_{j \in P} X_{i j}} P R O D Y_{k}
$$

The EXPY contribution level (EXPY_C) of an item in a country represents how much the item contributes to the EXPY of the country. Thus, goods with a high EXPY_C have a relatively significant influence on determining a country's EXPY index. For example, even when a country exports semiconductors, if the export proportion of the item is very low, its contribution to the EXPY index would be low. On the other hand, if a country exports clothing with low value but the export proportion of the item is high, its contribution to the EXPY index would be very high. As a result, clothing is the main export item that determines the EXPY contribution level of the country.

On the other hand, using the product space model, the industries with future comparative advantage of the country can be predicted. Hidalgo et al. (2007) and Hausmann and Klinger (2007) proposed a density index to measure the possibilities of a country's transition to a specific product. The density index was introduced to measure how closely a country's export industries surround a specific industry, and based on the index values, industries with future comparative advantage of the country can be predicted. A higher density index of a product in a country indicates a higher probability for the country to have a comparative advantage for the product in the future. The density index of item $k$ in country $i, w_{i k}$, is calculated as follows.

$$
w_{i k}=\frac{\sum_{j \in P} X_{i j} \varphi_{j k}}{\sum_{j \in P} \varphi_{j k}}
$$
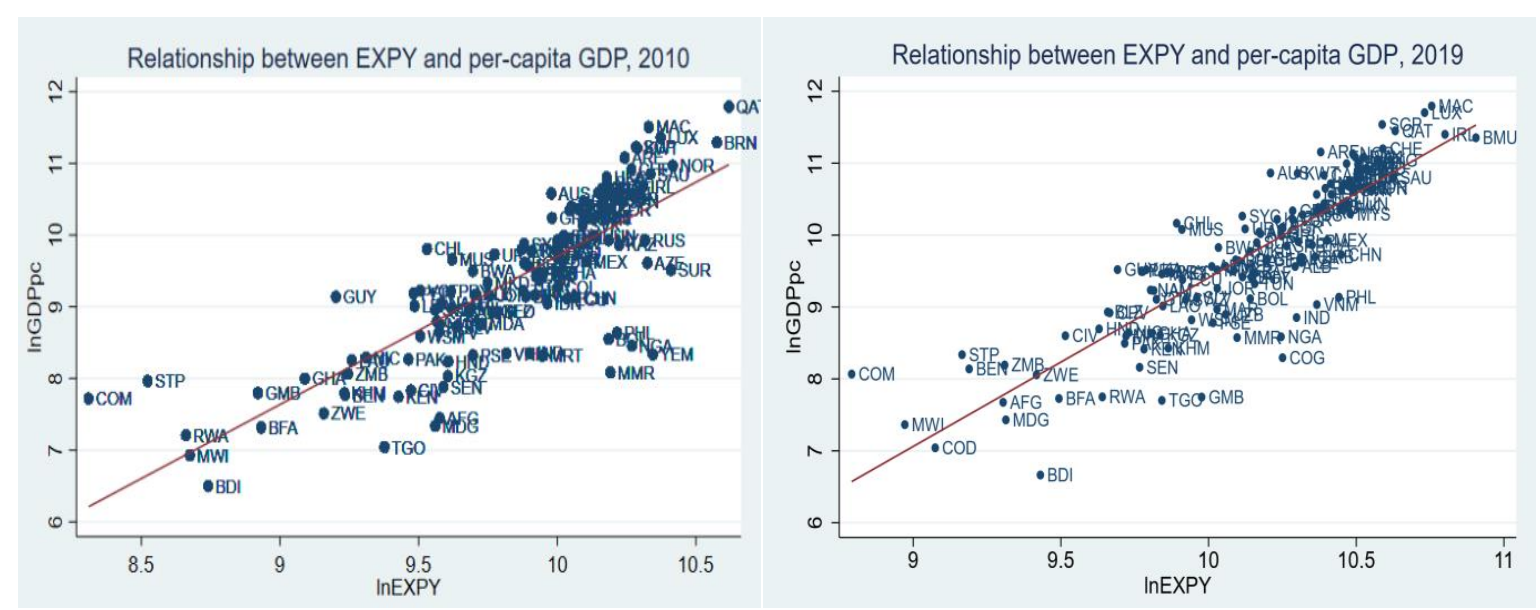

Figure 1. Relationship between EXPY index and GDP per capita in 2010 and 2019.

Source: Authors' calculations based on World Development Indicators and UN Comtrade data. 


\section{Major products and trade trends based on the product space model}

The most remarkable trend of PRODY in the world's top 20 items in the 2010-2019 period is the widening gap between hightech and other industries as can be seen from Table 1. That is, the PRODY value of high-tech items is larger on average than that of other products. In particular, during the 2010-2019 period, the gap in PRODY values between high-tech items and other

Table 1. PRODY index of the world's top 20 exported items (2010-2019)

\begin{tabular}{|c|c|c|c|c|c|c|}
\hline \multirow{2}{*}{ Rank } & \multicolumn{3}{|c|}{2010} & \multicolumn{3}{|c|}{2019} \\
\hline & Code & Description & PRODY & Code & Description & PRODY \\
\hline 1 & 2709 & $\begin{array}{l}\text { Petroleum oils and oils obtained from bituminous } \\
\text { minerals, crude }\end{array}$ & $31,454.8$ & 2709 & $\begin{array}{l}\text { Petroleum oils and oils obtained from bituminous } \\
\text { minerals, crude }\end{array}$ & $28,555.5$ \\
\hline 2 & 2710 & $\begin{array}{l}\text { Petroleum oils and oils obtained from bituminous } \\
\text { minerals (excluding crude); preparations } \\
\text { containing }\end{array}$ & $22,834.7$ & 9999 & Commodities not elsewhere specified & $41,922.8$ \\
\hline 3 & 8703 & $\begin{array}{l}\text { Motor cars and other motor vehicles principally } \\
\text { designed for the transport of persons, incl. }\end{array}$ & $26,447.0$ & 8703 & $\begin{array}{l}\text { Motor cars and other motor vehicles principally } \\
\text { designed for the transport of persons, incl. }\end{array}$ & $36,587.4$ \\
\hline 4 & 9999 & Commodities not elsewhere specified & $35,877.9$ & 8542 & Electronic integrated circuits; parts thereof & $44,988.1$ \\
\hline 5 & 8542 & Electronic integrated circuits; parts thereof & $35,812.3$ & 2710 & $\begin{array}{l}\text { Petroleum oils and oils obtained from bituminous } \\
\text { minerals (excluding crude); preparations } \\
\text { containing }\end{array}$ & $27,576.7$ \\
\hline 6 & 8517 & $\begin{array}{l}\text { Telephone sets, incl. telephones for cellular } \\
\text { networks or for other wireless networks; other }\end{array}$ & $31,304.6$ & 8517 & $\begin{array}{l}\text { Telephone sets, incl. telephones for cellular networks } \\
\text { or for other wireless networks; other }\end{array}$ & $41,912.8$ \\
\hline 7 & 8471 & $\begin{array}{l}\text { Automatic data-processing machines and units } \\
\text { thereof; magnetic or optical readers, machines }\end{array}$ & $24,758.5$ & 8708 & $\begin{array}{l}\text { Parts and accessories for tractors, motor vehicles for } \\
\text { the transport of ten or more persons, }\end{array}$ & $35,943.4$ \\
\hline 8 & 2711 & Petroleum gas and other gaseous hydrocarbons & $48,742.4$ & 3004 & $\begin{array}{l}\text { Medicaments consisting of mixed or unmixed } \\
\text { products for therapeutic or prophylactic uses, put }\end{array}$ & $42,297.0$ \\
\hline 9 & 8708 & $\begin{array}{l}\text { Parts and accessories for tractors, motor vehicles } \\
\text { for the transport of ten or more persons, }\end{array}$ & $25,505.6$ & 8471 & $\begin{array}{l}\text { Automatic data-processing machines and units } \\
\text { thereof; magnetic or optical readers, machines }\end{array}$ & $36,480.9$ \\
\hline 10 & 3004 & $\begin{array}{l}\text { Medicaments consisting of mixed or unmixed } \\
\text { products for therapeutic or prophylactic uses, } \\
\text { put }\end{array}$ & $28,271.9$ & 7108 & $\begin{array}{l}\text { Gold, incl. gold plated with platinum, unwrought or } \\
\text { not further worked than semi-manufactured }\end{array}$ & $13,699.9$ \\
\hline 11 & 7108 & $\begin{array}{l}\text { Gold, incl. gold plated with platinum, unwrought } \\
\text { or not further worked than semi-manufactured }\end{array}$ & $8,016.5$ & 2711 & Petroleum gas and other gaseous hydrocarbons & $46,681.4$ \\
\hline 12 & 8473 & $\begin{array}{l}\text { Parts and accessories (other than covers, carrying } \\
\text { cases and the like) suitable for use solely }\end{array}$ & $28,507.0$ & 3002 & $\begin{array}{l}\text { Human blood; animal blood prepared for therapeutic, } \\
\text { prophylactic or diagnostic uses; antisera }\end{array}$ & $63,961.8$ \\
\hline 13 & 8541 & $\begin{array}{l}\text { Diodes, transistors and similar semiconductor } \\
\text { devices; photosensitive semiconductor devices }\end{array}$ & $28,982.2$ & 8411 & Turbojets, turbo-propellers and other gas turbines & $49,775.3$ \\
\hline 14 & 8901 & $\begin{array}{l}\text { Cruise ships, excursion boats, ferry-boats, cargo } \\
\text { ships, barges and similar vessels for the }\end{array}$ & $24,642.4$ & 8704 & $\begin{array}{l}\text { Motor vehicles for the transport of goods, incl. } \\
\text { chassis with engine and cab }\end{array}$ & $30,039.1$ \\
\hline 15 & 7102 & $\begin{array}{l}\text { Diamonds, whether or not worked, but not } \\
\text { mounted or set (excluding unmounted stones } \\
\text { for pick-up) }\end{array}$ & $18,144.0$ & 9018 & $\begin{array}{l}\text { Instruments and appliances used in medical, surgical, } \\
\text { dental or veterinary sciences, incl. }\end{array}$ & $36,605.6$ \\
\hline 16 & 8528 & $\begin{array}{l}\text { Monitors and projectors, not incorporating } \\
\text { television reception apparatus; reception } \\
\text { apparatus }\end{array}$ & $25,426.0$ & 8544 & $\begin{array}{l}\text { Insulated "incl. enameled or anodized" wire, cable } \\
\text { "incl. coaxial cable" and other insulated }\end{array}$ & $18,333.3$ \\
\hline 17 & 8443 & $\begin{array}{l}\text { Printing machinery used for printing by means of } \\
\text { plates, cylinders and other printing } \\
\text { components }\end{array}$ & $32,424.8$ & 8473 & $\begin{array}{l}\text { Parts and accessories (other than covers, carrying } \\
\text { cases and the like) suitable for use solely }\end{array}$ & $43,031.7$ \\
\hline 18 & 2601 & $\begin{array}{l}\text { Iron ores and concentrates, incl. roasted iron } \\
\text { pyrites }\end{array}$ & $17,838.4$ & 2601 & Iron ores and concentrates, incl. roasted iron pyrites & $21,057.5$ \\
\hline 19 & 2701 & $\begin{array}{l}\text { Coal; briquettes, ovoids and similar solid fuels } \\
\text { manufactured from coal }\end{array}$ & $20,481.0$ & 7113 & $\begin{array}{l}\text { Articles of jewelry and parts thereof, of precious } \\
\text { metal or of metal clad with precious metal }\end{array}$ & $49,709.5$ \\
\hline 20 & 9013 & $\begin{array}{l}\text { Liquid crystal devices not constituting articles } \\
\text { provided for more specifically in other } \\
\text { heading }\end{array}$ & $29,540.1$ & 8541 & $\begin{array}{l}\text { Diodes, transistors and similar semiconductor } \\
\text { devices; photosensitive semiconductor devices }\end{array}$ & $39,570.3$ \\
\hline & Average & $\begin{array}{c}\text { All } \\
\text { High-tech } \\
\text { Non-high-tech }\end{array}$ & $\begin{array}{l}27,250.6 \\
29,075.3 \\
26,034.1\end{array}$ & Average & $\begin{array}{c}\text { All } \\
\text { High-tech } \\
\text { Non-high-tech }\end{array}$ & $\begin{array}{l}37,436.5 \\
41,695.7 \\
33,177.3\end{array}$ \\
\hline
\end{tabular}

Source: Authors' calculations based on International Trade Center's trade map and UN Comtrade data.

Note: Numbers in parentheses indicate percentile values and products of the shaded color are classified as high-tech products based on Lall (2000).

The products classification is presented in Appendix 1. 
items widened further. This trend implies that countries with high-income levels have strengthened their tendency to focus on exporting high-tech products. For example, the PRODY value of IC parts (8542) rises significantly from 35,812.3 in 2010 to 44,988.1 in 2019. In addition, products such as medical and related products (Code 3004, 3002, 9018) were first included in the top 20 items in the world trade, and all of these products have comparably high PRODY values.

The changes in the export competitiveness of major countries can be estimated from their EXPY indices during the 20102019 period, as depicted in Figure 2. The countries with the highest EXPY index are Japan and Germany, showing that the two countries have maintained the highest competitiveness in manufacturing for the past ten years. Korea's EXPY index has also surpassed that of the US since 2018, indicating that Korea is exporting relatively higher value-added items. The most noticeable change in the EXPY index in the past decade was a significant rise in the EXPY index shown by China and Vietnam.

As the top 20 EXPY_C contribution items, there is a difference in diversity in China and US (Table 2). China's top 20 EXPY_C items are concentrated on IT products $(8525,8471,8542,8517,8473,8541,8504,8543,8516,8518)$ and final consumer goods $(9503,4202,9405,9403,7113)$. On the other hand, in the US, petroleum products $(2710,2709,2711,3901)$, pharmaceutical products and facilities $(3002,9018,3004,9021)$, facilities and parts $(8479,9020,9027)$, IT products $(8542$, $8525,8471,8473)$, automobiles and related parts $(8703,8704)$, etc. are in the top 20 items.

Figure 3 shows the visualization of the proximity matrix obtained based on the HS 4-digit code of the UN Comtrade Database.

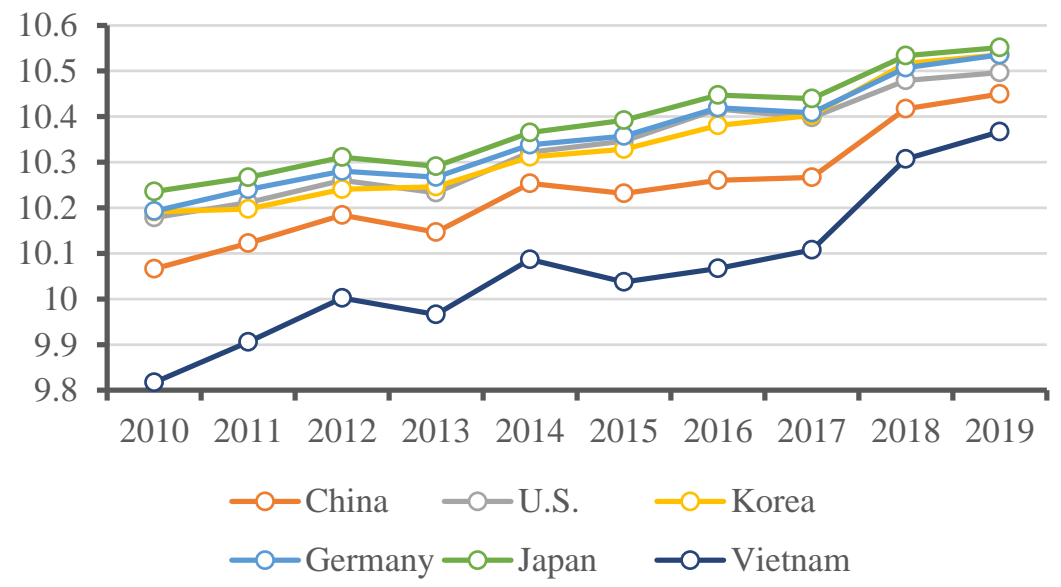

Figure 2. EXPY index of major countries for the 2010-2019 period.

Source: Authors' calculations based on World Development Indicators and UN Comtrade data.

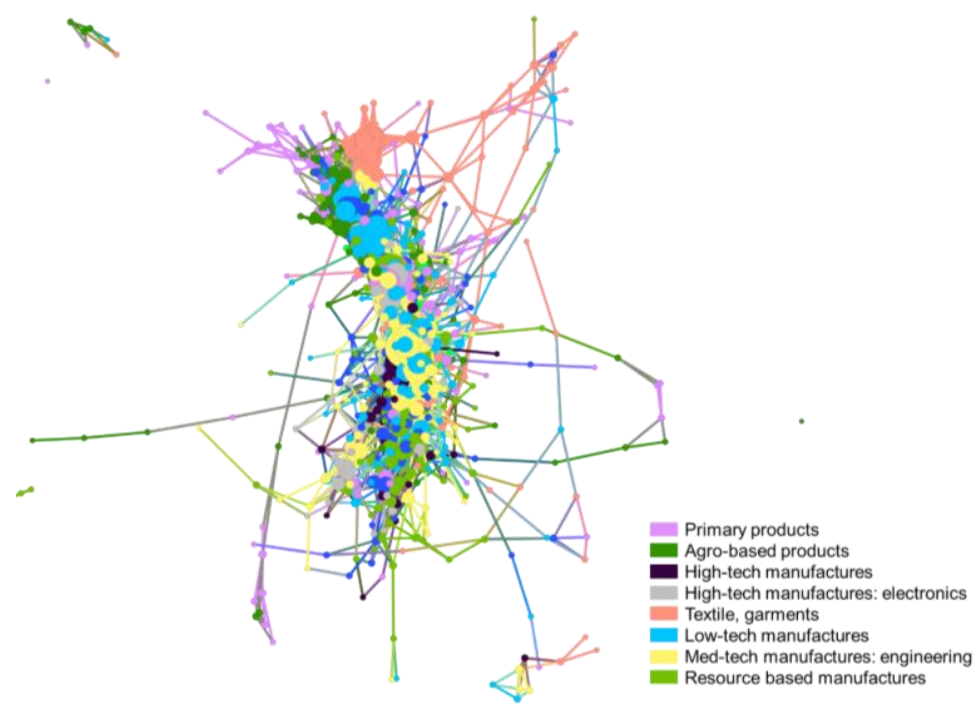

Figure 3. Proximity network in 2019 classified by the method of Lall (2000). 
Table 2. EXPY contribution level of China and US Top 20 exported goods (2010-2019)

\begin{tabular}{|c|c|c|c|c|c|}
\hline \multicolumn{3}{|c|}{ China } & \multicolumn{3}{|c|}{ US } \\
\hline Code & Description & EXPY_C & Code & Description & EXPY_C \\
\hline 8525 & Radio and TV transmitters, television cameras & 3,649 & 9999 & Commodities not elsewhere specified & 4,435 \\
\hline 8471 & $\begin{array}{l}\text { Automatic data processing machines } \\
\text { (computers) }\end{array}$ & 2,435 & 2710 & $\begin{array}{l}\text { Oils petroleum, bituminous, distillates, except } \\
\text { crude }\end{array}$ & 1,468 \\
\hline 8542 & $\begin{array}{l}\text { Electronic integrated circuits and micro } \\
\text { assemblies }\end{array}$ & 1,865 & 8703 & $\begin{array}{l}\text { Motor vehicles for transport of persons (except } \\
\text { buses) }\end{array}$ & 1,250 \\
\hline 8517 & Electric apparatus for line telephony, telegraphy & 833 & 2709 & $\begin{array}{l}\text { Petroleum oils, oils from bituminous minerals, } \\
\text { crude }\end{array}$ & 1,134 \\
\hline 8473 & $\begin{array}{l}\text { Parts, accessories, except covers, for office } \\
\text { machines }\end{array}$ & 564 & 8542 & $\begin{array}{l}\text { Electronic integrated circuits and micro } \\
\text { assemblies }\end{array}$ & 1,104 \\
\hline 8541 & Diodes, transistors, semi-conductors, etc. & 548 & 3002 & Blood, antisera, vaccines, toxins and cultures & 1,006 \\
\hline 8708 & Parts and accessories for motor vehicles & 484 & 8708 & Parts and accessories for motor vehicles & 940 \\
\hline 9503 & Other toys, scale models, puzzles, etc. & 451 & 8525 & Radio and TV transmitters, television cameras & 907 \\
\hline 4202 & Trunks, suit-cases, camera cases, handbags, etc. & 436 & 2711 & $\begin{array}{l}\text { Petroleum gases and other gaseous } \\
\text { hydrocarbons }\end{array}$ & 867 \\
\hline 2710 & $\begin{array}{l}\text { Oils petroleum, bituminous, distillates, except } \\
\text { crude }\end{array}$ & 423 & 9018 & $\begin{array}{l}\text { Instruments etc. for medical, surgical, dental, } \\
\text { etc. use }\end{array}$ & 662 \\
\hline 9405 & $\begin{array}{l}\text { Lamps and lighting fittings, illuminated signs, } \\
\text { etc. }\end{array}$ & 400 & 8471 & $\begin{array}{l}\text { Automatic data processing machines } \\
\text { (computers) }\end{array}$ & 624 \\
\hline 3926 & Plastic articles n.e.s. & 396 & 3004 & $\begin{array}{l}\text { Medicaments, therapeutic, prophylactic use, in } \\
\text { dosage }\end{array}$ & 588 \\
\hline 8504 & $\begin{array}{l}\text { Electric transformers, static converters and } \\
\text { rectifiers }\end{array}$ & 385 & 8473 & $\begin{array}{l}\text { Parts, accessories, except covers, for office } \\
\text { machines }\end{array}$ & 437 \\
\hline 9013 & $\begin{array}{l}\text { Liquid crystal devices, lasers, optical appliances } \\
\text { n.e.s. }\end{array}$ & 353 & 8479 & Machines nes having individual functions & 386 \\
\hline 8543 & Electrical machinery and apparatus, n.e.s. & 337 & 9010 & Equipment for photographic laboratories n.e.s. & 360 \\
\hline 9403 & Other furniture and parts thereof & 301 & 8481 & $\begin{array}{l}\text { Taps, cocks, valves for pipes, tanks, boilers, } \\
\text { etc. }\end{array}$ & 326 \\
\hline 8481 & Taps, cocks, valves for pipes, tanks, boilers, etc. & 288 & 8704 & Motor vehicles for the transport of goods & 312 \\
\hline 8516 & $\begin{array}{l}\text { Electric equipment with heating element, } \\
\text { domestic, etc. }\end{array}$ & 285 & 9027 & Equipment for physical and chemical analysis & 304 \\
\hline 7113 & Jewelry and parts, containing precious metal & 265 & 9021 & Orthopedic appliances & 295 \\
\hline 8518 & $\begin{array}{l}\text { Audio-electronic equipment, except recording } \\
\text { devices }\end{array}$ & 264 & 3901 & Polymers of ethylene, in primary forms & 289 \\
\hline & Sum & 14.962 & & Sum & 17,694 \\
\hline
\end{tabular}

Note: (\%) indicated the proportion of the product in China's total EXPY. Products in the shaded colour are high-tech products according to the classification of Lall (2000).

In addition, each item group was visualized with a different color, based on the Lall (2000)'s technological classification of products of low, medium, and high. The network in Figure 3 was visualized using the multilevel layout algorithm of Yifan $(2005)^{4}$, In the figure, the size of the node means centrality. Nodes with high centrality are located in the center of the network and thus significantly influence other industries. This visualization showed that high and medium-tech items are clustered to some degree and concentrated in the center area in the network. In Figure 4, high technology industries are clustered in the center of the network.

Figure 5 shows the locations of items with RCA of the US and China in 2010 and 2019 in the visualized product space network. The size of nodes in Figure 5 indicates RCA indices. China is shown to have items with RCA in all areas, encompassing items in the periphery area and high-tech items in the core area. Especially in 2019, items with higher RCA are relatively more concentrated in the core area. These results imply that China maintains a comparative export advantage in hightech industries and low-tech, peripherally located products. The visualization is consistent with the trend of the top 20 EXPY contribution items in Table 2.

\footnotetext{
${ }^{4}$ The force-directed graph algorithm facilitates clustering while minimizing distances between nodes. As a result, Euclidean distance is approximately proportional to the geodesic distance between two nodes. That is, this algorithm tries to represent the ideal distance between nodes that aren't adjacent to each other.
} 


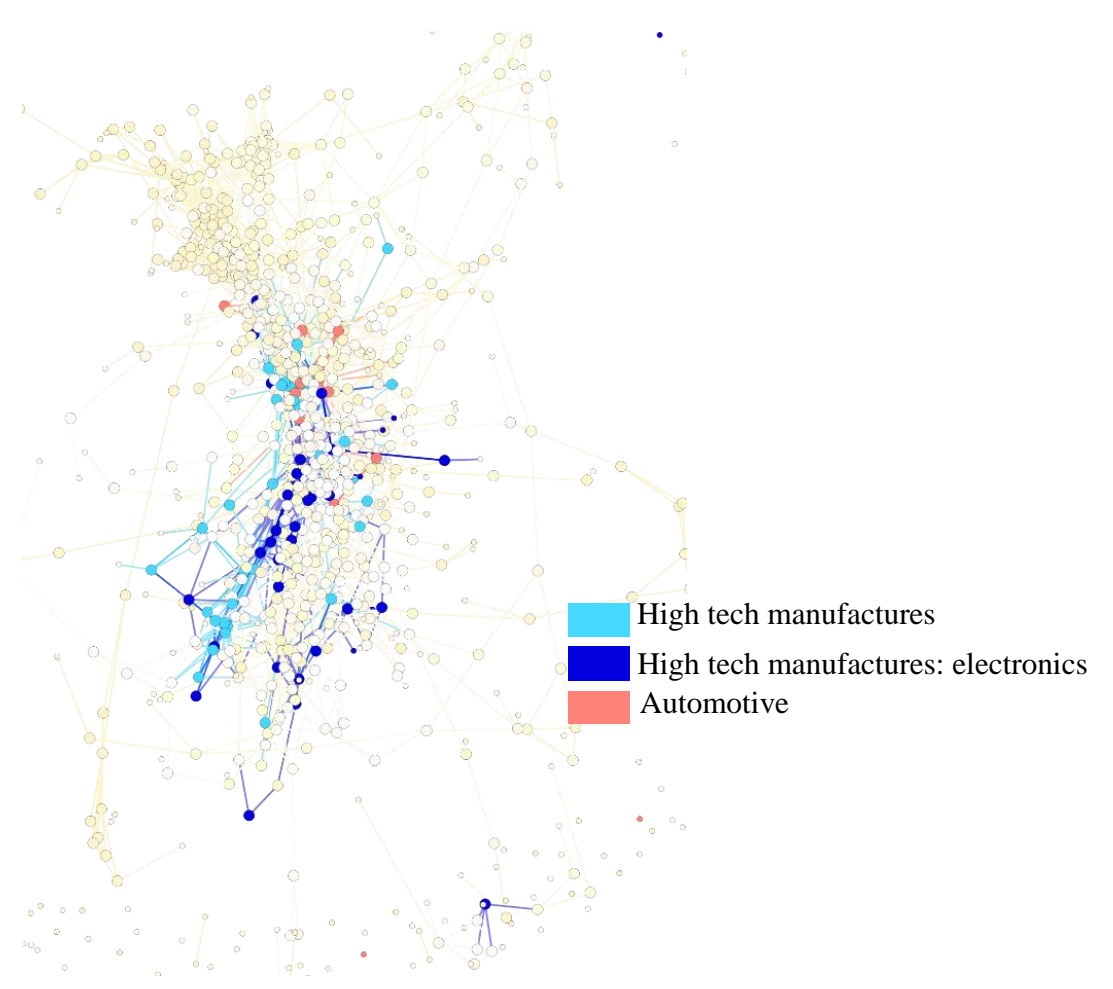

Figure 4. Locations of the high-tech products classified by the method of Lall (2000).

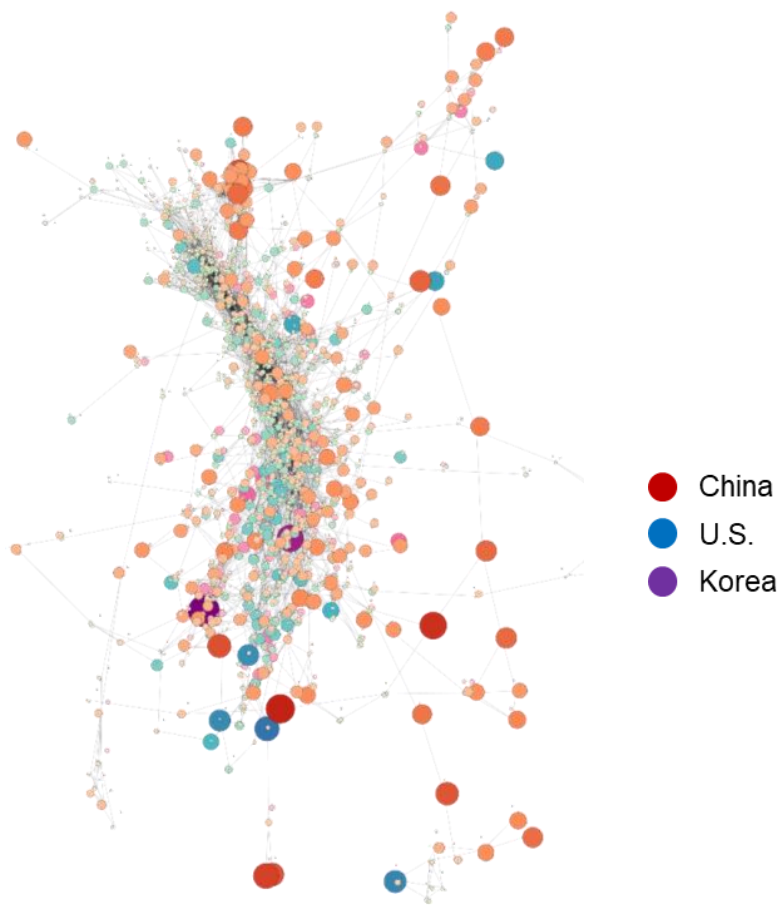

(a) Product space in 2010

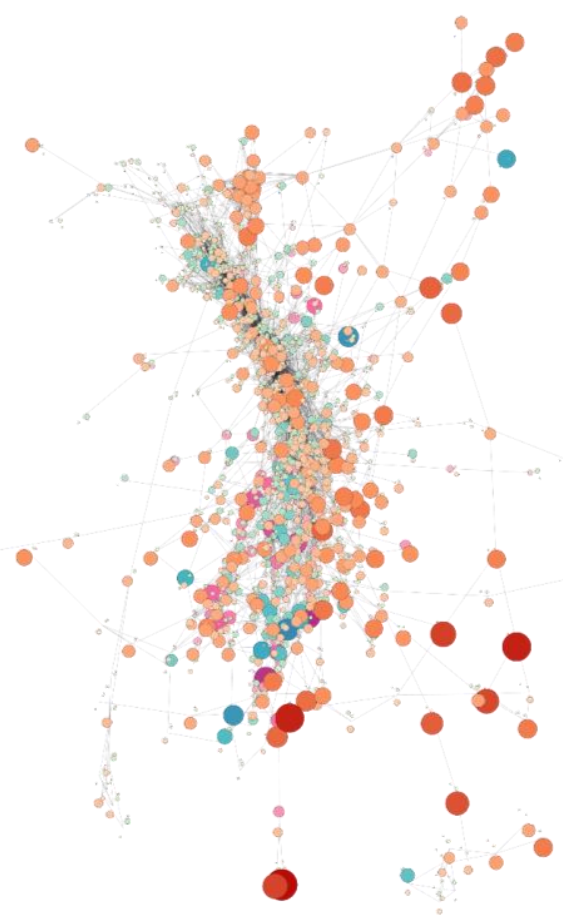

(b) Product space in 2019

Figure 5. Positions of China and US in the product space.

\section{China's industrial upgrade}

As in the analogy of Hidalgo et al. (2007), the proximity network of products can be envisioned as a forest comprised of the 
trees of products as described above. At this time, it may be possible to quantify the possibility upgrading of the industrial structure of each country by obtaining the relative value for the possibility that monkeys can move from the first tree to another tree. For this purpose, the production path index (PATH) is first calculated. The PATH index is the sum of paths between all trees in a forest. In other words, it is the sum of all proximities of the product space network of a country. Therefore, the PATH index for each country is a constant. Then, to estimate the possibility of export sophistication of a specific item, density is calculated by dividing the sum of proximities connected to the specific item by the PATH index and normalizing the quantity. The density measures the average proximity of a new product to a country's current production network (Hidalgo et al. 2007). Therefore, density is a quantified value of a country's possibility of accessing other industries in the current product network. This concept is based on the hypothesis that the complexity of products with comparative advantage of each country determined the income level (Hidalgo and Hausmann 2009). Another hypothesis underlying the notion is that a high diversity of products with comparative advantage of each country and exporting items with low ubiquity are linked to economic growth, i.e., the process of increasing economic complexity is economic growth.

In addition, this approach is consistent with the previous study finding that proximity and density contribute to export sophistication (Kali et al. 2013). It also agrees with Poncet and de Waldemar's (2015) results using actual data of Chinese companies. Poncet and de Waldemar (2015) found that the density of links between products generates export-enhancing spillovers, which means that the intra-regional density level contributes to the growth of exports.

Major countries' average trends of EXPY_C representing current industrial competitiveness and density indicating the possibility of the industrial upgrade were examined by classifying industries into low-, medium-, and high-tech industries (Figure 6). As a result, it was found that Germany consistently maintained competitiveness in high-tech industries, Korea in medium-tech industries, and China in low-tech industries during the 2010-2019 period. However, in high- and medium-tech industries, China has consistently shown a lower competitiveness level compared to major countries. On the other hand, in the trend of changes in density, which indicates the possibility of an industrial upgrade, China showed a very high level of competitiveness in low-tech industries. The interesting point is that China has begun to show the level of competitiveness higher than that of the US, even in medium- and high-tech industries since the mid-2010s.

Semiconductors (8542), a key item in US-China trade war, are a representative high-tech item and a fiercely competitive item in US-China industrial competition. For the 8542 item, the level of competitiveness of China, as evaluated by EXPY_C, is low. On the other hand, with respect to future competitiveness, which is indicated by density, China has maintained the top
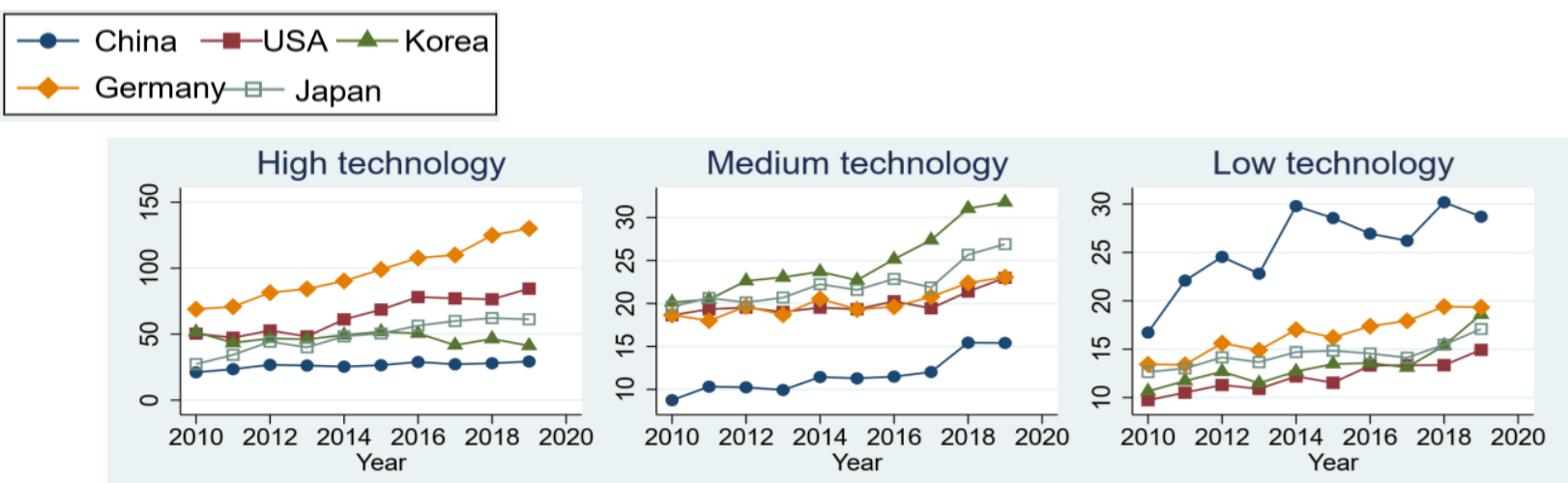

(a) Average EXPY_C
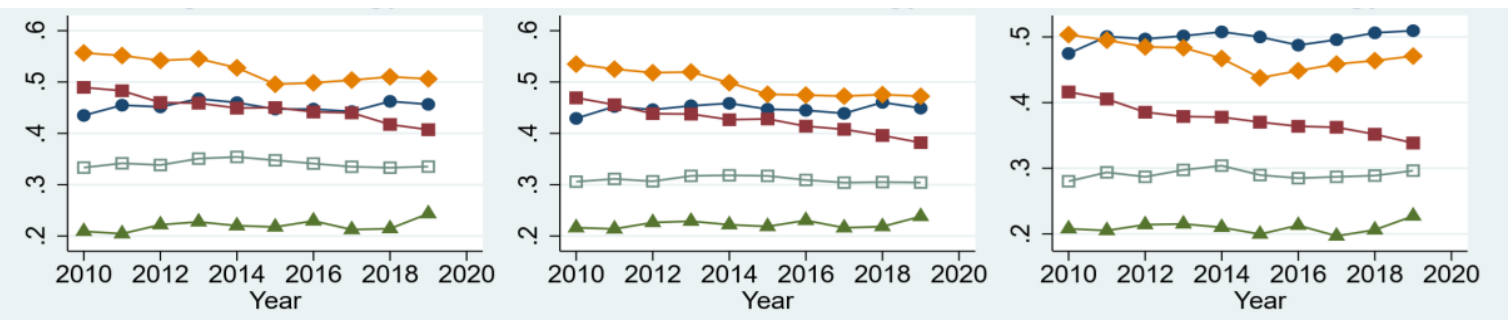

(b) Average density

Figure 6. Average EXPY_C and average density of major countries by technological level during the 2010-2019 period.

Source: Authors' calculations based on UN Comtrade data. 
Table 3. EXPY_C and density of semiconductors (8542) by country

\begin{tabular}{|c|c|c|c|c|c|c|}
\hline & & 2010 & 2012 & 2014 & 2016 & 2019 \\
\hline \multirow[t]{5}{*}{ EXPY_C } & US & $1,065(10)$ & 747 (12) & 786 (12) & $1,000(13)$ & $1,104(13)$ \\
\hline & China & $690(11)$ & $886(11)$ & $976(11)$ & $1,233(11)$ & $1,865(9)$ \\
\hline & Korea & $2,912(6)$ & $2,508(7)$ & $3,292(6)$ & $4,365(5)$ & $6,565(5)$ \\
\hline & Japan & $1,610(7)$ & $1,275(9)$ & $1,354(9)$ & $1,548(9)$ & $1,778(10)$ \\
\hline & Germany & $301(15)$ & $263(17)$ & 349 (15) & 389 (15) & 458 (16) \\
\hline \multirow[t]{5}{*}{ Density } & US & $0.53(1)$ & 0.45 (2) & $0.35(6)$ & $0.34(6)$ & $0.32(8)$ \\
\hline & China & $0.47(3)$ & 0.57 (1) & 0.63 (1) & $0.62(1)$ & 0.63 (1) \\
\hline & Korea & $0.34(9)$ & $0.32(10)$ & $0.34(7)$ & $0.34(7)$ & $0.36(5)$ \\
\hline & Japan & $0.45(4)$ & $0.43(4)$ & $0.45(2)$ & $0.42(2)$ & $0.46(2)$ \\
\hline & Germany & 0.47 (2) & 0.45 (3) & $0.42(3)$ & 0.39 (3) & 0.39 (3) \\
\hline
\end{tabular}

Source: Authors' calculations based on UN Comtrade data.

Note: Numbers in parentheses represent global rankings.

position since 2012 (Table 3). Naturally, it is necessary to take into account the fact that since the HS 4-digit code, which is a broad category of items, was used, products of very different technological levels are included even in the category of semiconductors. Also, there is a need to consider that a significant part of China's exports in the high-tech industries are produced by foreign-invested companies in China. It is also necessary to consider the fact that an aggressive firms' innovation capability policy of the Chinese government enabled China to overcome the development trap in its exported goods, as suggested by the results of Desmarchelier et al. (2018), who converted a product space model into an agent-based model. However, even when these several factors are taken into account, it is indisputable that China has shown comparative advantage in production and exports in many high-tech industrial sectors and demonstrated a remarkable trend of technological development.

\section{Concluding remarks}

This study evaluated the industrial competitiveness levels of major countries, including the US and China. using the product space model. This practical analysis tool can analyze international trade, economic growth, and industrial development. For this purpose, this study constructed product proximity network, PRODY index, EXPY index, Density index for the 2010-2019 period. Using these indices, this study analyzed the trends of industrial competitiveness and future industrial competitiveness of major manufacturing countries such as the United States, China, Germany, Japan, and Korea during the 2010-2019 period. Major implications for the analysis are derived as follows.

First, China's export sophistication trend was prominently observed. The network visualization, taking into account technological levels, showed that China's main export items are located in the periphery area of the product network. Still, China entered the middle- and high-tech products in the core area to a considerable degree during the 2010-2019 period. China's possibility of industrial upgrade, which was assessed by the density of the product network, was shown to have already surpassed that of the US in 2018. Second, despite the possibility of China's export sophistication, its current industrial competitiveness is concentrated in low-tech industries. As for high-tech items, China has shown a trend of lower export sophistication, compared to major manufacturing powerhouses such as Germany, the US, Japan and Korea.

Since the product space model is based on the comparative advantage represented by exports, it may lead to overestimating the competitiveness of countries with a relatively high proportion of manufacturing and thus underestimating the competitiveness of service and R\&D powerhouses such as the US. In addition, it may distort the competitiveness of each country in high-tech industries that depend on the competitiveness of specific items due to the product classification based on the broad categories of the HS 4-digit code. Nevertheless, it is unquestionable that China has demonstrated its export competitiveness in various industrial sectors in the past decade and has continued to increase the complexity of its industrial structure, showing a transition from the past economic structure dependent on labor-intensive industries. In addition, it is also a distinct trend that China's level of density has already approximated the levels of major manufacturing powerhouses since the mid-2010s, increasing the possibility of China's industrial upgrade in the field of high-tech industries.

These trends of China's export sophistication and industrial upgrade are sufficient factors to agitate the US and trigger the 
US-China trade war. However, as implied by studies based on the trade-growth theory, including the product space model proposed by Hidalgo et al. (2007), a country's industrial competitiveness can be enhanced only by the evolution of industrial structure through participation in international trade. Therefore, China's responses to US-China industrial competition should be implemented to ensure further openness and industrial complexity. In this context, the current dual circulation strategy of the Chinese government should also be premised on active participation in international trade.

Hence, this study can draw implications for the widespread system competition between the US and China. The determining factors on the US-China system competition are continuous economic growth and industry competitiveness. China postures the world's second-largest economy after entering World Trade Organization, which will boost economic exchanges between countries and expand its advantage in various industries as suggested by the product space model. In the same context, it will guarantee a long-term systemic advantage for countries that maintain openness and expand the diversity of industries.

This research can be extended in several directions. First, a product space model was established through industrial classification of HS 4-digit in this study. However, to reflect more correctly the global division of labor system, it is needed to use a more divided industry classification such as HS 6-digit to build a product space model focusing on a specific industry such as IT industry. Second, it is meaningful to utilize the ubiquity and sophistication indices that can better reflect the complexity of each country's industry.

\section{Acknowledgements}

This work was supported by Global Research Network program through the Ministry of Education of the Republic of Korea and the National Research Foundation of Korea (NRF-2017S1A2A2041812).

\section{References}

Baldwin, R., 2016. The Great Convergence: Information Technology and the New Globalization. The Belknap Press of Harvard University Press, Cambridge, MA.

Chen, L., Naughton, B., 2016. A dynamic China model: the co-evolution of economics and polictics in China. Journal of Comtemporary China 26(103), 1-17.

Cicerone, G., McCann, P., Venhorst, V. A., 2020. Promoting regional growth and innovation: Relatedness, revealed comparative advantage and the product space. Journal of Economic Geography 20, 293-316.

Colotla, I., Zhou, Y., Wong, J., Walters, J., Rose, J., Maecker, L., 2018. China's next leap in manufacturing. Boston Consulting Group. Available at: https://www.bcg.com/publications/2018/china-next-leap-in-manufacturing

De Benedictis, L., Tajoli, L., 2011. The world trade network. The World Economy 34, 1417-1454.

Deloitte, 2016. Global manufacturing competitiveness index. Available at: https://www2.deloitte.com/global/en/pages/ manufacturing/articles/global-manufacturing-competitiveness-index.html

De La Cruz, J., Riker, D., 2012. Product Space Analysis of the Exports of Brazil. U.S. International Trade Commission, Washington, DC.

Desmarchelier, B., Regis, P. J., Salike, N., 2018. Product space and the development of nations: A model of product diversification. Journal of Economic Behavior \& Organization 145, 34-51.

Ferrarini, B., Scaramozzino, P., 2015. The product space revisited: China's trade profile, the world economy. Wiley Blackwell 38(9), 1368-1386.

Freund, C., Ferrantino, M., Maliszewska, M., Ruta, M., 2018. Impacts on Global Trade and Income of Current Trade Disputes. MTI Practice Notes. World Bank, Wahsington, DC.

Hass, R., Denmark, A. M., 2020. More pain than gain: How the U.S.-China trade war hurt America. Availalbe at: https://www.brookings.edu/blog/order-from-chaos/2020/08/07/more-pain-than-gain-how-the-us-china-trade-war-hurt-america/

Hamwey, R., Pacini, H., Assunção, L., 2013. Mapping green product spaces of nations. The Journal of Environment \& Development 22, 155-168.

Hausmann, R., Hwang, J., Rodrik, D., 2007. What you export matters. Journal of Economic Growth 12, 1-25.

Hausmann, R., Klinger, B., 2007. The structure of the product space and the evolution of comparative advantage, CID Working Papers 146, Center for International Development at Harvard University.

Hidalgo, C. A., Klinger, B., Barabási, A. L., Hausmann, R., 2007. The product space conditions the development of nations. Science 317, 482-487. 
Hidalgo, C. A., Hausmann, R., 2009. The building blocks of economic complexity. Proceedings of the National Academy of Sciences of the United States of America 106, 10570-10575.

Huang, Y., Smith, J., 2020. In the U.S.-China Trade War, New Supply Chains Rattle Markets. Carnegie Endowment for International Peace, Washington, DC.

Itakura, K., 2020. Evaluating the impact of the US-China trade war. Asian Economic Policy Review 15, 77-93.

Kali, R., Reyes, J., McGee, J., Shirrell, S., 2013. Growth networks. Journal of Development Economics 101, 216-227.

Kim, S. M., Shin, E. H., 2002. A longitudinal analysis of globalization and regionalization in international trade: A social network approach. Social Forces 81, 445-468.

Lall, S., 2000. The technological structure and performance of developing country manufactured exports, 1985-98. Oxford Development Studies. 28. 337-369.

Lee, B., Park, J., 2017. Structural transformation of exports in a product space model: The case of Daegu-Gyeongbuk province, Korea. Korea Trade Review 42, 47-67.

Lee, B., Son, W., 2019. A Comparative Analysis of Structural Changes of Korea, China, and Japan in Product Space, Structural Transformation of Exports in a Product Space. Korea Institute for International Economic Policy, Sejong, Korea.

Nahm, J., Steinfeld, E. S., 2014. Scale-up nation: China's specialization in innovative manufacturing. World Development 54, 288-300.

Pacini, H., Shi, G., Sanches-Pereira, A., da Silva Filho, A. C., 2021. Network analysis of international trade in plastic scrap. Sustainable Production and Consumption 27, 203-216.

Poncet, S., de Waldemar, F. S., 2015. Product relatedness and firm exports in China. The World Bank Economic Review 29, $579-605$.

UNIDO, 2020. Competitive Industrial Performance Report 2020. United Nations Industrial Development Organization, Vienna, Austria.

Walmsley, T., Minor, P., 2018. Estimated impacts of US sections 232 and 301 trade actions on the US and global economies: A supply chain prospective 2018-2030. ImpactECON, Boulder, CO.

Wei, S. J., Xie, Z., Zhang, X., 2016. From "Made in China" to "Innovated in China": Necessity, prospect and challenges. Journal of Economic Perspectives 31, 49-70.

WTO, 2020. An economic analysis of the US-China trade conflict. Staff Working Papers ERSD-2-2.

$\mathrm{Hu}, \mathrm{Y} ., 2005$. Efficient and high quality force-directed graph drawing. Mathematica Journal 10, 37-71.

Zhang, F., Gallagher, K.S., 2016. Innovation and technology transfer through global value chains: evidence form China's PV Industry. Energy Policy 94, 191-203. 
Appendix 1. Technology classification based on Lall (2000)

\begin{tabular}{|c|c|c|}
\hline Classification & Code & Description \\
\hline \multirow[t]{7}{*}{ Low technology } & 2601 & Iron ores and concentrates, roasted iron pyrites \\
\hline & 2709 & Petroleum oils, oils from bituminous minerals, crude \\
\hline & 2710 & Oils petroleum, bituminous, distillates, except crude \\
\hline & 2711 & Petroleum gases and other gaseous hydrocarbons \\
\hline & 4202 & Trunks, suitcases, camera cases, handbags, etc. \\
\hline & 7113 & Jewelry and parts, containing precious metal \\
\hline & 9503 & Other toys, scale models, puzzles, etc. \\
\hline \multirow[t]{7}{*}{ Medium technology } & 8443 & Printing and ancillary machinery \\
\hline & 8471 & Automatic data processing machines (computers) \\
\hline & 8525 & Radio and TV transmitters, television cameras \\
\hline & 8703 & Motor vehicles for transport of persons (except buses) \\
\hline & 8704 & Motor vehicles for the transport of goods \\
\hline & 8708 & Parts and accessories for motor vehicles \\
\hline & 8901 & Passenger and goods transport ships, boats \\
\hline \multirow{12}{*}{ High technology } & 3002 & Blood, antisera, vaccines, toxins and cultures \\
\hline & 3004 & Medicaments, therapeutic, prophylactic use, in dosage \\
\hline & 8411 & Turbojets, turbo-propellers/other gas turbine engines \\
\hline & 8471 & Automatic data processing machines (computers) \\
\hline & 8473 & Parts, accessories, except covers, for office machines \\
\hline & 8517 & Electric apparatus for line telephony, telegraphy \\
\hline & 8528 & Television receivers, video monitors, projectors \\
\hline & 8541 & Diodes, transistors, semi-conductors, etc. \\
\hline & 8542 & Electronic integrated circuits and micro-assemblies \\
\hline & 8544 & Insulated wire and cable, optical fiber cable \\
\hline & 9013 & Liquid crystal devices, lasers, optical appliances \\
\hline & 9018 & Instruments etc. for medical, surgical, dental, etc. use \\
\hline \multirow[t]{2}{*}{ Unclassified products } & 7108 & Gold, unwrought, semi-manufactured, powder form \\
\hline & 9999 & Commodities not elsewhere specified \\
\hline
\end{tabular}

